\title{
A Learning Journal to Improve the Ability of Students in Critical Thinking
}

\author{
Imam Nawawi \\ Elementary School Teacher Education \\ Universitas Negeri Malang \\ Malang, Indonesia \\ imam.mawawi.fip@um.ac.id
}

\author{
Putri Mahanani \\ Elementary School Teacher Education \\ Universitas Negeri Malang \\ Malang, Indonesia \\ putri.mahanani.fip@um.ac.id
}

\author{
Arda Purnama Putra \\ Elementary School Teacher Education \\ Universitas Negeri Malang \\ Malang, Indonesia \\ arda.purnama.fip@um.ac.id
}

\begin{abstract}
The social problem of the 21 st century is greater than the complexity of cognitive capacity. To overcome these problems, students need to be provided in the form of learning patterns, namely: textual learning, contextual learning and problem-solving. Student's activeness will arise if the lecturer gives problem-solving to the students in order to develop their mindset and want to express ideas with critical thinking. Critical thinking is an active process and way of thinking regularly and systematically in order to understand the information more deeply, then form a belief about the truth of the information obtained or opinions conveyed. This ability is required by students in this 21 st century. The ability to think critically can be improved with the right learning pattern. One way to improve the ability to think critically is to use a learning journal.
\end{abstract}

Keywords - development research, a learning journal, critical thinking

\section{INTRODUCTION}

The complexity of social problems in the 21 st century is greater than the complexity of cognitive capacity, resulting in a mystery of life, if not prepared critical thinking patterns [1]. To overcome them students need to be equipped in the form of learning patterns, namely: textual, contextual and problem-solving.The student activeness will emerge if the lecturer provides problem-solving to students so they want to develop their mindset and want to express ideas with critical thinking. Students can think critically from reasoning a problem that exists in the community if they understand the problems of society as a whole.

Critical thinking is one of the high-level skills that are very important to be taught to students in addition to creative thinking skills [2]. In critical thinking, we practice or include careful evaluation or evaluation, such as assessing the feasibility of an idea or product. From some of the opinions of the experts above, it can be interpreted that critical thinking is an active process and a way of thinking regularly and systematically to understand information in depth, then form a belief about the truth of the information obtained or opinions conveyed. Active processes indicate that desire and/or motivation to find answers and achieve understanding [3].

Learning journal is a term translated from learning journals which is a document that is constantly increasing and developing, [4]. Learning journals are often written by learners, as a record of the development of the material being studied. Nowadays there are many online learning journals, where students can conduct dialogues (such as in forum form), even students from other schools can join.

Learning journals are not a summary of learning material, but rather focus on students' reflections on what has been read or are being studied. The learning journal is also not the same as the learning catalog, because in the study catalog the time and date of teaching are written. A catalog is a record of events, but learning journals are recordings of reflections and observations and thoughts of students.

Learning journals are not the same as scientific papers that are compiled according to the criteria or requirements for writing and language used. Learning journals are generally written as an appreciation of learning. Student comments on learning. These comments may be due to interest, there is a problem because they do not understand until the new findings from the students themselves, which may be different from what the teacher taught. Learning journals are not the same as diaries, which can be filled with "likes" by the owner. But there are similarities with diaries or diaries. The learning journal is filled with students at the time provided by the teacher and is only related to learning in school.

The use of Learning Journal can improve cognitive abilities and metacognitive abilities of Sabilu [5]. This is in line with research conducted by Setiawan \& Susilo [6] which states that the application of learning journals can improve students' metacognitive skills. The ability to think critically is strongly influenced by cognitive abilities and metacognitive abilities. So that the use of learning journals can improve students' critical thinking skills.

\section{LITERATURE REVIEW}

\section{A. 21st Century Life Skills}

According to the Departemen Pendidikan Nasional [7], life skills are skills that go to school for people who want and dare to face the problems of life and life naturally without difficulty, finally proactively and creatively looking for and finding the right solution to overcome them

ATCS (assessment and teaching for 21st-century skills) More than one thing called 21 st-century skills, namely ways of thinking, ways of working, work tools and life skills. Thinking ways to overcome creativity, critical thinking, problem-solving, decision making and learning. How it works complements communication and collaboration. 
Tools for working include information and communication technology (ICT) and information literacy.

Kang, Kim, Kim \& You [8] provide time for 21stcentury skills in the cognitive, affective, and social culture domains. Cognitive domains are divided into subdomains: the ability to manage information, namely the ability to use tools, resources and skills in the discovery process; Allows constructing knowledge by processing information, giving reasons, and thinking critically; ability to use analytical knowledge, assess, evaluate, and solve problems; and problem-solving skills by using the ability of metachogicism and creative thinking.

Mohsin [9] the 21st century has a complexity of difficulty. Therefore, skill is needed in overcoming various possible difficulties. Mohsin stated the characteristics of 21st century students who have skills: (1) critical thinking; (2) Resolve problems; (3) Communicate; (4) Collaborate; (5) Life and cooperation; (6) Learning and Innovation; (7) Media, technology and communication; (8) Mastering the subject of the terrace in school. The skills that should be possessed in the 21st century are: (1) Digital Age Literacy; (2) Effective Communication; (3) Copyrighted Thinking; (4) High Productivity; (5) Cognitive Proficiency; (6) Adaptation Skills; (7) Interpersonal skills; (8) Attitude Skills, Values and Work Practices; and (9) Terrace Proficiency [9].

\section{B. Critical Thinking}

The ability to think critically is one of the capital that is very important for everyone in living life. Penner in Dwijananti [10] states that this ability is a fundamental part of human maturity. Critical thinking is reasoning and reflective thinking by emphasizing decision making about what to believe and do (Hassoubah in Dwijananti [10]).

Zamroni and Mahfudz [11] suggest that there are six arguments that are the basis for solving the problems they face critically. Fourth, critical thinking is the key to developing creativity, where creativity arises because of seeing phenomena that will require us to think creatively. Fifth, a lot of work both directly and indirectly, requires awareness, or as a teacher or critical thinking is the key to success. Sixth, every time humans are always faced with decision making, willing or not, intentionally or not, sought or not will be needed for critical thinking.

People who think critically will evaluate and then conclude a fact-based thing to make a decision. According to Hassoubah in Dwijananti [10], one of the characteristics of people who think critically will always seek and explain the relationship between the problems discussed with the problem or other relevant experiences. Carin \& Sund stated about the category of people who think critically have the ability to: (1) classify; (2) assume; (3) predict and hypothesis; (4) interpret data, differentiate or make conclusions; (5) measure; (6) design an investigation; (7) observe; (8) making graphs; (9) minimize trial errors; (10) evaluate; (11) analyze [10].

\section{Learning Journal}

Learning journal is interpreted as a document that continuously increases and develops, usually written by a learner to record every progress of learning [12]. Learning journal is an active learning method, students are required to know their shortcomings in mastering the subject matter, after that it is not only enough to know it, but to think about how to overcome it [13].

According to Surapranata [11]) learning journals or also called learning journals is one of the appropriate means to strengthen the communication system between teachers and students in the teaching and learning process. Learning journal which is an active learning method contains learning reflections written by students after the learning process, students can also write down their experiences during the learning process, then the material or concepts that have not been understood or understood can be written in a learning journal. This can establish communication or sharing learning between teachers and students.

The contents of a learning journal can be in the form of (1) Recording interesting things and want to be followed up more deeply than a book or article read; (2) Record the questions that come to mind about the topic of material that is read or studied; (3) Record about the main things that have just been known from the material that has been studied; (4) Recording relevant material from other sources that have been read, such as articles in newspapers; (5) Record anything that has been found related to the material being studied or read, in the form of one or two sentences and write down how to find it; (6) Record about reflection on what has been learned, to what extent it has been able to meet the learning needs; (7) Record about the way learning is done in relation to what is learned in different ways; (8) Noting thoughts includes a reflection of feelings from what is learned, learning progress, and theories that develop in his mind [12].

\section{DISCUSSION}

Critical thinking is a skill that must be possessed by students in the 21 st century. The ability to think critically bridges students' competence with the world of work. The world of work in the 21 st century really needs the ability to think more deeply about seeing things in order to find a new idea that is more creative and innovative.

Brolin [14] suggests that life skills are the knowledge and abilities needed by people who are never patient and safe in everyday life. So it can be concluded that the form of life skills as praxis and tips (praxis and techne), not theory; knowledge as a skill to do skills while being.

In realizing these things, learning in schools must be creative there are 4Cs, namely: (1) Communication, adhering learning to constructivism theory; (2) Collaboration, the student learning process is carried out by providing information from others; (3) Critical Thinking and Problem Solving, learning must be based on problems that can generate different sources. (4) Creativity and Innovation, the community must condition students to create innovation and develop their creativity [7]. This is supported by Mohsin's statement which states that skills that should be possessed in the 21st century include Cognitive Proficiency [9]. In this skill, critical thinking is an unbiased part of 
cognitive skills. This further shows that critical thinking is very important to be developed in school.

According to Potter [15], there are three reasons for critical thinking. First, keep the information. At this time there was an explosion of information that came from thousands of web search engines on the internet. Information from various kinds can be many outdated, incomplete, or not credible. To be able to use this information properly, it is necessary to conduct data and related information. The ability to evaluate and then decide to use repeat information critical thinking. Therefore, thinking skills need to be developed in students.

Second, including global challenges. At present, there is a serious global crisis, poverty, and hunger everywhere. To overcome this condition, research and development of critical thinking skills are needed. Third, the increase in the amount of citizens' knowledge. So far people under 25 can already online their news. Some information that cannot be used and may even be deliberately misleading, is contained on the internet. In order for students not to get lost in taking so much available information, it is necessary to anticipate. Students will search for information from the web will not be wrong or biased information.

Learning journals are documents that continually increase and develop. Usually written by students (learners), as a record of the development of the material being studied. Learning journal is a place to write down students' reflections on the learning that has been followed. How student responses are written in learning journals, for example, the material has been understood, learning material has not been understood by writing down the reasons why it is not understood, explanations that are different from what the educator conveyed from other learning resources.

Learning journals are very useful to improve writing skills and habits, compile a written mindset, which for lecturers can be a reference in assessing whether or not students learn the material presented [8]. This is consistent with Hassoubah's statement in Dwijananti [10] which states that one of the characteristics of people who think critically is that they will always look for and explain the relationship between the problems discussed with the problem or other relevant experiences. The existence of learning journals is very possible for students to develop their critical thinking skills because they are asked to be able to evaluate and create the results of their thoughts. This is supported by Carin \& Sund's statement also states one category of people who think critically that has the ability: classify, assume, analyze, interpret data, differentiate or make conclusions, and evaluate [10].

The form of learning journals can be in the form of small sheets of paper, such as a pocketbook so that they can easily write down what they think of what they learned. A more modern form can use Mobile to take notes. After that, it is necessary to rewrite it in a special journal so that it becomes a permanent reference. In learning journals, it is very possible that there are opinions or results of our thinking about the topic being studied.
Based on the discussion above can be found several studies that have been conducted to prove that learning journals can improve cognitive, metacognitive and student learning outcomes. Increasing one's cognitive abilities will have an impact on increasing one's ability to think critically.

Many experimental studies have been conducted to determine the impact of the use of learning journals on metacognitive and cognitive processes and learning performance. Research from Andrea R. McCrindle, Carol A. Christensen [16] found that the use of learning journals can improve cognitive abilities, metacognitive abilities, and also improve learning outcomes. This is in line with the research of Ana-Maria Cazan [8] who suggested that learning journals succeeded in improving cognitive and metacognitive abilities that produced better learning outcomes.

Based on previous studies, it has been proven that the use of learning journals can improve cognitive and metacognitive abilities. Benjamin Bloom defines cognitive ability to be six levels: remembering, understanding, implementing, analyzing, evaluating, and creating. The ability to analyze, evaluate, and create is a high-level thinking ability that is also commonly said to think critically. While this metacognitive ability is an awareness of thinking about what is known and what is not known. In the context of learning, students know how to learn, know the abilities and learning modalities they have and know the best learning strategies for effective learning. Cognitive and metacognitive abilities are very influential on the ability to think critically.

\section{CONCLUSION}

Based on the literacy studies that have been conducted and explained above about the use of learning journals to improve students 'critical thinking skills, it can be concluded that the use of learning journals can improve students' critical thinking skills. This ability includes the ability to classify, assume, analyze, interpret data, differentiate or make conclusions, and evaluate. Learning journals can be in the form of a pocketbook, a special book, or using a mobile phone in recording various thoughts related to what is learned. Several studies that have been conducted proving that the use of learning journals can improve cognitive and metacognitive abilities that affect students' critical thinking abilities.

\section{REFERENCES}

[1] I. Goldin and K. Kuntarna, "Age of Discovery," J. Navig. RENAISANCE, 2016.

[2] B. DePorter, dkk, Quantum Learning: Membiasakan Belajar Nyaman dan Menyenangkan. Bandung: Kaifa, 2013.

[3] S. Hendra, Cara Belajar Orang Genius. Jakarta: Elex Media Komputindo, 2013.

[4] S. Arif Rohman, "MGMP IPS SMP Provinsi Jawa Timur." 2016.

[5] M. Sabilu, "Pengaruh Penggunaan Jurnal Belajar dalam Pembelajaran Multistrategi terhadap Kemampuan Kognitif dan Metakognitif Siswa SMA Negeri 9 Malang," Program Pascasarj. UM, 2008.

[6] D. Setiawan and H. Susilo, "Peningkatan keterampilan metakognitif mahasiswa program Studi biologi melalui penerapan jurnal belajar dengan Strategi jigsaw dipadu PBL berbasis lesson study Pada matakuliah biologi umum." Prosiding Seminar Nasional Pendidikan Biologi, 2015. 
[7] Depdiknas, "Pedoman Pelaksanaan Pendidikan Kecakapan Hidup." Depdiknas, 2002.

[8] A. MariaCazan, "Enhancing self regulated learning by learning journals," Procedia-Soc. Behav. Sci., vol. 33, pp. 413-417, 2012.

[9] S. Faizzatul Aqmal Binti Mohamad Mohsin and H. Razali Bin, "Pengajaran dan Pembelajaran berasaskan 'Streaming Video' bagi meningkatkan tahap kefahaman pelajar Abad ke-21," Persidang. Kebangs. Penyelid. Dan Inov. Dalam Pendidik. Dan Latih. Tek. Dan Vokasional, 2011.

[10] D. P and Y. D, "Pengembangan Kemampuan Berpikir Kritis Mahasiswa Melalui Pembelajaran Problem Based Instruction Pada Mata Kuliah Fisika Lingkungan,” J. Pendidik. Fis. Indones., vol. 6 , pp. 108-114, 2010
[11] Z. Mahfudz, Panduan Teknis Pembelajaran Yang Mengembang-kan Critical Thinking. Jakarta: Depdiknas, 2009.

[12] A. Sudrajat, "Jurnal Pembelajaran." 2010.

[13] A. Suprijono, Cooperative Learning. Yogyakarta: Pustaka Pelajar, 2012.

[14] B. D.E, Life Centered Career Education: A Competency Based Approach. Reston VA: The Council for Exepctional Children, 1989.

[15] M. Lane Potter, "From Search to Research: Developing Critical Thinking Through Web Research Skills." Microsoft Corporation, 2010.

[16] A. R, M. Carol, and A. Christensen, "The impact of learning journals on metacognitive and cognitive processes and learning performance," J. Learn. Instr., vol. 5, no. 2, pp. 167-185, 1995. 